\title{
Analisis Yuridis Kewenangan Pemerintah Desa Dalam Pengelolaan Dana Desa Untuk Kesehatan Di Kabupaten Banyumas ${ }^{1}$
}

\author{
Alan Bayu Aji dan Kartika Dwi Chandra Sari \\ Fakultas Ilmu Sosial Universitas Harapan Bangsa Banyumas Jawa Tengah Indonesia \\ Jln. Raden Patah No. 100, Ledug Kembaran Banyumas Jawa Tengah Indonesia \\ alanbayuaji@gmail.com; kartikadwichandra@uhb.ac.id
}

Received: 4 Desember 2020; Accepted: 28 Mei 2021; Published: 25 Agustus 2021

DOI: 10.20885/iustum.vol28.iss3.art7

\begin{abstract}
This research departs from the use of village funds which are still oriented towards infrastructure development in the midst of the low Human Development Index in Banyumas Regency which is influenced by the level of community health. The purpose of the research is to identify first, the authority of the Village Government in the use of village funds for health sector activities according to applicable regulations. Second, the role of the Village Government in utilizing village funds for health sector activities in Banyumas Regency. Third, the Village Fund utilization model for future public health activities. The research method used is normative juridical with statutory, case and conceptual approaches. The results of the study show that first, the authority of the village government for the utilization of village funds in the health sector is regulated in the Minister of Village Regulation Number 01 of 2015. Second, it was found that the role played by the village government in 50 villages in Banyumas is still lacking, it is proven that only $6 \%$ allocation of village funds for health. Third, the model that will be built in the future is the use of a bottom-up system in village development planning, health census, formation of peer education as well as socialization and periodic monitoring from the government.
\end{abstract}

Key Words: Health; village funds; village government authority

\section{Abstrak}

Penelitian ini berangkat dari penggunaan dana desa yang masih berorientasi untuk pembangunan infrastruktur di tengah Indeks Pembangunan Manusia yang masih rendah di Kabupaten Banyumas yang dipengaruhi tingkat kesehatan masyarakat. Adapun tujuan dari penelitian adalah mengetahui pertama, kewenangan Pemerintah Desa dalam pemanfaatan dana desa untuk kegiatan bidang kesehatan menurut peraturan yang berlaku. Kedua, peran Pemerintah Desa dalam pemanfaatan dana desa untuk kegiatan bidang kesehatan di Kabupaten Banyumas. Ketiga, model pemanfaatan Dana Desa untuk kegiatan bidang kesehatan masyarakat di masa yang akan datang. Metode penelitian yang digunakan yuridis normatif dengan pendekatan perundang-undangan, kasus dan konseptual. Hasil penelitian menyimpulkan, pertama, bahwa kewenangan yang dimiliki pemerintah desa untuk pemanfaatan dana desa bidang kesehatan diatur dalam Peraturan Menteri Desa Nomor 01 Tahun 2015. Kedua, ditemukan bahwa peran yang dilakukan oleh pemerintah desa di 50 desa di Banyumas masih kurang, terbukti hanya $6 \%$ alokasi dana desa untuk kesehatan. Ketiga, model yang akan dibangun di masa yang akan datang adalah penggunaan sistem buttom up dalam perencanaan pembangunan desa, sensus kesehatan, pembentukan peer education dan juga sosialisasi dan monitoring berkala dari pemerintah.

Kata-kata Kunci: Dana desa; kewenangan pemerintah desa; kesehatan

1 Artikel ini merupakan hasil dari Penelitian yang didanai dari Hibah Dikti Tahun 2019 dalam kegiatan Penelitian Dosen Pemula Tahun 2019 dengan Judul: Pemanfaatan Dana Desa untuk Pemenuhan Pelayanan Dasar Kesehatan Masyarakat (studi Penggunaan Dana Desa di Wilayah Kabupaten Banyumas) 


\section{Pendahuluan}

Pergeseran paradigma pembangunan dari pembangunan ekonomi ke pembangunan sumber daya manusia terjadi di akhir abad ke 20 dimana pembangunan dengan parameter ekonomi tidak lagi mencerminkan keberhasilan pembangunan karena hanya diukur dari peningkatan pendapatan per kapita yang tidak mencerminkan keadilan juga pemerataan. Paradigma pembangunan ekonomi kemudian diganti menjadi pembangunan sumber daya manusia oleh PBB melalui UNDP (United Nation Development Programes) dimana paradigm tersebut tidak hanya mengukur keberhasilan pembangunan dari income per kapita namun menggunakan indeks kualitas sumber daya manusia (Human Development Index) atau HDI. Indeks HDI tersebut ditentukan melalui tiga komponen yakni pendidikan, kesehatan, dan ekonomi. ${ }^{2}$

Adapun dalam pembangunan nasional Indonesia dalam UU No. 17 Tahun 2007 tentang Pembangunan Jangka Panjang Nasional Tahun 2005-2025 menjelaskan mengenai salah satu yang harus dipenuhi guna mewujudkan bangsa yang berdaya saing adalah pembangunan sumber daya manusia, yang ditandai dengan Indeks Pembangunan Manusia (IPM) 3 yang perlu ditingkatkan salah satunya dalam rangka mencapai derajat kesehatan setingginya. ${ }^{4}$ Kesehatan dan pembangunan manusia tidak dapat dipisahkan karena kesehatan adalah salah satu hak asasi manusia terlebih sebagai satu bagian dari paradigm pembangunan nasional era baru.

Kesehatan sebagai satu Hak Asasi mengharuskan negara untuk memenuhinya. Beberapa instrument hukum baik Internasional maupun nasional telah merumuskan bahwasanya kesehatan menjadi satu hak asasi yang harus dipenuhi. Instrumen Internasional adalah dalam Pasal 25 Deklarasi Hak Azasi Manusia PBB atau DUHAM (Declaration of Human Right) menyatakan bahwa

2 Soekidjo, "Kesehatan dan Pembangunan Sumber Daya Manusia". Jurnal Kesehatan Masyarakat Nasional Vol. 2, No. 5, April 2010, hlm. 196

${ }^{3}$ IPM adalah salah satu hal yang mendasari pembangunan untuk mencapai kesejahteraan manusia sebagai tujuan akhir pembangunan. IPM memberi wawasan pembangunan yang lebih luas karena pembentukannya didesain untuk memfokuskan perhatian pada aspek pembangunan kesehatan dan pendidikan, sehingga bisa mengetahui perbandingan kinerja pembangunan manusia antar negara maupun antar daerah.

4 Adelfina dan Jember, I Made, "Pengaruh Pertumbuhan Ekonomi, Kemiskinan, dan Belanja Daerah Terhadap Indeks Pembangunan Manusia Di Kabupaten Kota Provinsi Bali Periode 2005-2013.” E-Jurnal Ekonomi Pembangunan Universitas Udayana. Vol.5. No. 10 Oktober 2016. ISSN: 2303-0178, hlm. 1012 
Everyone has right to standard of living adequate for health and well being of himself and his family, including food, clothing, housing and medical care. Artinya bahwa setiap manusia memiliki hak sama dalam memperoleh standar hidup layak untuk kesehatan. Intrumen internasional lainnya adalah Pasal 12 Kovenan Internasional tentang Hak Ekonomi, Sosial, dan Budaya, Pasal 12 Konvensi tentang Penghapusan Segala Bentuk Diskriminasi terhadap Perempuan, dan Pasal 24 Konvensi tentang Hak-Hak Anak. Adapun dalam instrumen hukum nasional Hak atas kesehatan terdapat dalam Pasal 28H ayat (1) dan Pasal 34 ayat (3) UUD 1945, kemudian dalam Pasal 9 UU No. 39 Tahun 1999 tentang Hak Asasi Manusia dan di dalam UU No. 36 Tahun 2009 tentang Kesehatan. ${ }^{5}$

Pembangunan kesehatan adalah upaya pemerintah melalui berbagai kebijakan untuk memenuhi hak dasar berupa kesehatan yang layak bagi seluruh masyarakat tanpa terkecuali. Namun, dalam praktiknya masih terdapat banyak kendala dalam pelaksanaan pemenuhan kesehatan bagi masyarakat yakni kondisi geografis, Sumber Daya Manusia (SDM) kesehatan, pemerataan, sistem pelayanan dan bahkan partisipasi dari masyarakat itu sendiri. ${ }^{6}$ Salah satu upaya untuk mewujudkan pemenuhan kesehatan bagi masyarakat adalah dengan munculnya program Indonesia sehat melalui keputusan Menteri Kesehatan R.I Nomor HK.02.02/Menkes/52/2015 tentang Rencana Strategis Kementerian Kesehatan 2015-2019 yang selanjutnya dituangkan dalam penjabaran Rencana Pembangunan Jangka Menengah Nasional (RPJMN) 2015-2019.7 Program Indonesia Sehat sendiri memiliki sasaran meningkatkan derajat kesehatan serta status gizi masyarakat melalui upaya kesehatan dan pemberdayaan masyarakat dengan didukung oleh perlindungan finansial dan pemeratan pelayanan kesehatan. Salah satu upaya perwujudan pemberdayaan masyarakat sebagai satu upaya kesehatan adalah melalui Upaya Kesehatan Bersumberdaya Masyarakat (UKBM) dengan pemanfaatan dana desa.

\footnotetext{
${ }^{5}$ Rif 'atul Hidayat, "Hak Atas Derajat Pelayanan Kesehatan Yang Optimal”, SYARIAH Jurnal Hukum dan Pemikiran, Vol. 16, No. 2, Desember 2016, hlm. 127-134

${ }^{6}$ Maman Saputra, "Program Jaminan Kesehatan Nasional Dari Aspek Sumber Daya Manusia Pelaksana Pelayanan Kesehatan”, KEMAS Jurnal Kesehatan Masyarakat, Vol. 11 No. 1, 2015, hlm 32-42

7"Program Indonesia Sehat dengan Pendekatan Keluarga", https://www.kemkes.go.id/article/view/ 17070700004/program-indonesia-sehat-dengan-pendekatan-keluarga.html, diakses pada 25 November 2020
} 
Dana desa lahir sebagai amanat dari Undang-Undang Nomor 6 Tahun 2014 tentang Desa dimana undang-undang tersebut menegaskan pengakuan negara terhadap eksistensi Pemerintahan Desa melalui kebijakan dana desa yang berasal dari APBN. Pemerintah pusat yang di dalamnya menjelaskan tentang bentuk pengakuan negara terhadap eksistensi Pemerintahan Desa, di mana salah satu bentuk pengakuan tersebut adalah adanya kebijakan Dana Desa yang berasal dari APBN Pemerintah Pusat dan diperuntukan untuk Pemerintah Desa. Era baru dana desa melalui rezim undang-undang desa berlatar belakang dari harapan mengenai Pembangunan desa yang memiliki peranan strategis dan penting dalam rangka pembangunan nasional dan daerah karena desa adalah unsur yang bersentuhan langsung dengan kepentingan masyarakat guna meningkatkan kesejahteraan masyarakat. Adanya era undang-undang desa menjadikan desa menjadi subjek pembangunan bukan lagi objek pembangunan. ${ }^{8}$

Meskipun kebijakan dana desa telah diterapkan semenjak 2015, namun, dana desa masih berfokus pada pembangunan infrastruktur dibandingkan dengan pembangunan manusia. Hal tersebut bertolak belakang dengan paradigma arah pembangunan nasional di Indonesia yang bukan hanya berpacu pada output namun pada outcome. ${ }^{9}$ Namun dalam praktik pelaksanaan dana desa yang sudah berjalan semenjak 2015 masih banyak ditemukan pengalokasian yang mayoritas peruntukannya untuk pembangunan infrastruktur fisik dan bukan pembangunan manusia. Data dari Kementerian Keuangan Republik Indonesia menyebutkan bahwa Penyaluran dan Realisasi Penyerapan Dana Desa adalah untuk Pembangunan infrastruktur sebesar Rp. 14.210.000.000.000,00 atau sebesar $(82,21 \%)$ sedangkan dana desa untuk pemberdayaan masyarakat sebesar Rp. 1.370.000.000.000,00 atau sebesar (7,7\%) dan dana desa untuk Pembinaaan Kemasyarakatan sebesar Rp. 610.000.000.000,00 atau sebesar (3,51\%). ${ }^{10}$ Melihat data tersebut dapat disimpulkan bahwa pembangunan infrastruktur

\footnotetext{
${ }^{8}$ Kushandajani, "Konstruksi Hukum Pemerintahan Desa: pemikiran Perubahan Kebijakan bagi Desa". POLITIKA, Jurnal Magister Ilmu Politik UNDIP, Vol. 2 No. 1, April 2011, hlm. 32

9 Paradigma pembangunan berbasis outcome adalah bagaimana proses pembangunan tidak hanya mengarah pada hasil kerja atau output namun pada dampak dari hasil kerja. Outcomes dapat diartikan sebagai sesuatu yang berharga yang didapatkan dari pembangunan yang diberikan kepadanya. Misalnya seperti peningkatan kapasitas dan pemberdayaan untuk pembangunan manusia. Hal ini sejalan pula dengan konsep penganggaran berbasis Kinerja.

${ }^{10}$ Kementerian Keuangan RI, Buku Saku Dana Desa. Kemenkeu, Jakarta, 2018, hlm. 11
} 
mendominasi penyaluran dana desa. Dampak dari pembangunan infrastruktur bukan berarti buruk karena tujuannya adalah untuk pemerataan ekonomi, namun ketersediaan infratsruktur perlu diikuti dengan peningkatan sumber daya manusia (SDM) melalui pembangunan manusia yang layak agar tidak menjadi sebuah bangsa yang pasif. ${ }^{11}$

Menurut data BPS pada 2018 nilai Indeks Pembangunan Manusia Kabupaten Banyumas mendapatkan nilai 71,3.12 Apabila dibandingkan dengan Kabupaten/Kota di Jawa Tengah nilai IPM Kabupaten Banyumas masih di bawah rata-rata dengan nilai 71,79.13 Walaupun tidak terlampau buruk, dengan adanya kebijakan Dana Desa seharusnya dapat secara efektif meningkatkan nilai Indek Pembangunan Manusia yang dipengaruhi oleh kehidupan sehat dan standar hidup dengan layak. Namun, kondisi di lapangan ditemukan alokasi dana desa yang peruntukannya sebagian besar untuk pembangunan infrastruktur dengan prosentase 70\% pembangunan infrastruktur dan 30\% pemberdayaan masyarakat. Bahkan sejumlah Pemerintah desa (Pemdes) di Kabupaten Banyumas memanfaatkan Dana Desa 2019 untuk mengembangkan potensi pariwisata melalui pembangunan infrastruktur. ${ }^{14}$ Dari 50 desa di Kabupaten Banyumas sebagai subyek penelitian ditemukan jumlah anggaran pengalokasian dana desa untuk pembangunan sejumlah Rp. 56.901.227.122,00 dan untuk kesehatan hanya sebesar Rp. 3.802.787.270,00 Melihat data pengalokasian anggaran dana desa di Kabupaten Banyumas, jumlah anggaran pembangunan infrastruktur masih mendominasi dalam pemanfaatan dana desa di tengah nilai Indeks Pembangunan Manusia yang masih di bawah rata-rata, padahal sebenarnya alokasi dana desa 2019 kesehatan menjadi salah satu prioritas peruntukan dana desa yakni melalui

11 Ahmad Mustofa, “Analisis Pengaruh Sumber Daya Manusia, Infrastruktur Ekonomi Dan Social Capital Terhadap Pertumbuhan Ekonomi” eCo-Buss, Vol. 1, No.1, Agustus 2018, hlm. 60

12 “Indeks Pembangunan Manusia Kabupaten Banyumas Tahun 2014-2018” https://banyumaskab. bps.go.id/statictable/2019/08/22/181/indeks-pembangunan-manusia-kabupaten-banyumas-tahun-2014-

2018.html diakses 25 November 2020

13 "Indek Pembangunan Manusia Kabupaten/Kota di Jawa Tengah Tahun 2018" https://ipm.bps.go.id/data/provinsi/metode/baru/3300 diakses pada 24 November 2020

14 "Pemdes Banyumas manfaatkan Dana Desa kembangkan pariwisaata", https://jateng.antaranews. com/berita/208476/pemdes-banyumas-manfaatkan-dana-desa-kembangkan-pariwisaata diakses pada 24 November 2020 
program Upaya Kesehatan Bersumberdaya masyarakat (UKBM), Gerakan Masyarakat Hidup Sehat dan lainnya ${ }^{15}$.

\section{Rumusan Masalah}

Berdasarkan latar belakang tersebut, terdapat tiga rumusan malasah. Pertama, bagaimana kewenangan pemerintah desa dalam pemanfaatan dana desa untuk kegiatan bidang kesehatan menurut peraturan yang berlaku? Kedua, bagaimana peran pemerintah desa dalam pemanfaatan dana desa untuk kegiatan bidang kesehatan di Kabupaten Banyumas? Ketiga, bagaimana model pemanfaatan dana desa untuk kegiatan bidang kesehatan masyarakat di masa yang akan datang?

\section{Tujuan Penelitian}

Adapun tujuan dari penelitian adalah mengetahui pertama, kewenangan pemanfaatan dana dalam pemanfaatan dana desa untuk kegiatan bidang kesehatan menurut peraturan yang berlaku. Kedua, peran pemanfaatan dana dalam pemanfaatan dana desa untuk kegiatan bidang kesehatan di Kabupaten Banyumas. Ketiga, model pemanfaatan dana desa untuk kegiatan bidang kesehatan masyarakat di masa yang akan datang.

\section{Metode Penelitian}

Penelitian ini merupakan jenis penelitian yuridis normatif dengan menggunakan pendekatan perundang-undangan (statute approach) dan pendekatan kasus (case approach) dan pendekatan konseptual. Data yang digunakan adalah data sekunder berupa bahan hukum primer berupa peraturan perundang-undangan terkait dana desa dan data laporan realisasi penggunaan dana desa di Kabupaten Banyumas. Sedangkan bahan hukum sekunder berupa buku, jurnal dan literatur terkait dana desa. Sedangkan bahan hukum tersier berupa sumber lain non hukum.

15 Peraturan Menteri Kesehatan Nomor 65 Tahun 2013 tentang Pedoman Pelaksanaan dan Pembinaan Pemberdayaan Masyarakat bidang Kesehatan, dan Peraturan Menteri Desa Nomor 16 Tahun 2018 tentang Prioritas Penggunaan Dana Desa 2019. 


\section{Hasil Penelitian dan Pembahasan}

\section{Kewenangan Pemerintah Desa dalam Pemanfaatan Dana Desa untuk Kegiatan Bidang Kesehatan Menurut Peraturan yang Berlaku}

Undang-Undang Nomor 6 Tahun 2014 tentang Desa memberikan pengertian Desa adalah Desa dan desa adat atau yang disebut dengan nama lain, selanjutnya disebut Desa, adalah kesatuan masyarakat hukum yang memiliki batas wilayah yang berwenang untuk mengatur dan mengurus urusan pemerintahan, kepentingan masyarakat setempat berdasarkan prakarsa masyarakat, hak asalusul, dan/atau hak tradisional yang diakui dan dihormati dalam sistem pemerintahan Negara Kesatuan Republik Indonesia. ${ }^{16}$

Definisi dan makna sebagaimana dijelaskan di atas, menurut M. Salahudin, menempatkan desa sebagai organisasi campuran (hybird) antara masyarakat berpemerintahan (self governing community) dengan pemerintahan lokal (local self goverment). Dengan begitu, sistem pemerinahan di desa berbentuk pemerintahan berdasarkan masyarakat atau pemerintahan berbasis masyarakat dengan segala kewenangannya (authority). Desa juga tidak lagi identik dengan pemerintahan desa dan kepala desa semata, melainkan pemerintahan desa yang sekaligus pemerintahan masyarakat yang membentuk kesatuan entitas hukum. Artinya, masyarakat juga mempunyai kewenangan dalam mengatur desa sebagaimana pemerintahan desa. ${ }^{17}$

Kewenangan Desa tidak terlepas dari arti sebenarnya dari otonomi desa. Menurut Zudan Arif, kekhasan otonomi desa, minimal dapat ditinjau dari dua aspek. Pertama, otonomi desa bukan merupakan implikasi dari adanya penyerahan kewenangan dari pemerintahan pusat atau pemerintahan daerah kepada pemerintahan desa melalui kebijakan desentralisasi penyelenggaraan pemerintahan, meskipun dalam kedudukan pemerintahan desa sebagai subsistem dari pemerintahan nasional, tetap diatur pula tentang hubungan keuanagan serta hubungan pembinaan dan pengawasan antara pemerintah pusat dan pemerintah daeran dengan pemerintahan desa. Kedua, otonomi desa diselenggarakan berdasarkan hak asal usul dari adat istiadat masyarakat setempat, sehingga

16Pasal 1 angka 1 Undang-Undang Nomor 6 Tahun 2014 tentang Desa

${ }^{17}$ M. Slahudin, Buku 1 Kewenangan Desa dan Regulasi Desa, Cetakan Pertama, Kementrian Desa PDTT RI, Jakarta, 2015, hlm, 12 
otonomi desa lebih bermakna sebagai otonomi masyarakat desa dalam mengatur dan mengurus kepentingan bersama sesuai dengan sistem nilai sosial budaya masyarakat setempat, meskipun dalam pelaksanaannya perlu menggunakan pola administrasi modern. Hal ini berimplikasi pada penggunaan "istilah desa atau sebutan lain", seperti nagari, kampung, hura, bori, atau marga, serta memfungsikan lembaga adat untuk mendukung proses penyelenggaraan pemerintahan desa. ${ }^{18}$

Pemerintahan desa sangat penting peranannya dalam pembangunan nasional dikarenakan pemerintah desa adalah pemerintahan yang secara langsung berhubungan dengan masyarakat desa. menjadi fokus penting dalam pembangunan pemerintah. Hal ini disebabkan wilayah Indonesia sebagian besar berada di daerah pedesaan. Data yang dikutip dari databoks menunjukan bahwa terdapat 83.931 wilayah administrasi setingkat desa di Indonesia pada 2018.19

Sebagai negara hukum pengaturan mengenai sejarah pengaturan Desa beberapa kali mengalami perubahan hingga terakhir munculnya Undang-Undang Nomor 6 Tahun 2014 tentang Desa. Beberapa peraturan tersebut yakni :

1. Undang-Undang Nomor 22 Tahun 1948 tentang Pokok Pemerintahan Daerah;

2. Undang-Undang Nomor 1 Tahun 1957 tentang Pokok-Pokok Pemerintahan Daerah;

3. Undang-Undang Nomor 18 Tahun 1965 tentang Pokok-Pokok Pemerintahan Daerah;

4. Undang-Undang Nomor 19 Tahun 1965 tentang Desa Praja Sebagai Bentuk Peralihan Untuk Mempercepat Terwujudnya Daerah Tingkat III di Seluruh Wilayah Republik Indonesia;

5. Undang-Undang Nomor 5 Tahun 1974 tentang Pokok-Pokok Pemerintahan di Daerah;

6. Undang-Undang Nomor 5 Tahun 1979 tentang Pemerintahan Desa;

7. Undang-Undang Nomor 22 Tahun 1999 tentang Pemerintahan Daerah:

8. Undang-Undang Nomor 32 Tahun 2004 tentang Pemerintahan Daerah;

9. Undang-Undang Nomor 6 Tahun 2014 tentang Desa

10. Undang-Undang Nomor 6 Tahun 2014 tentang Desa

18 Zudan Arif Fakrulloh, Hukum Indonesia dalam Berbagai Prespektif, cetakan pertama, Raja Grafindo Persada, Jakarata, 2014, hlm. 74

19 "Jumlah Desa di Indonesia 2018", https://databoks.katadata.co.id/datapublish/2019/06/13/berapajumlah-desa-di-indonesia, diakses pada 26 November 2020 
Undang-Undang Nomor 6 Tahun 2014 tentang Desa menjadi barometer awal bagi desa untuk memetakan ulang kewenangan desa. Kewenangan tersebut kemudian diperjelas dengan adanya Permendesa Nomor 01 Tahun 2015 tentang Pedoman Kewenangan Berdasarkan Hak Asal Usul Dan Kewenangan Lokal Berskala Desa. Adanya regulasi tersebut memberi peluang bagi desa untuk menentukan nasibnya sendiri dalam hal perencanaan, pelaksanaan hingga evaluasi pembangunan desa untuk kepentingan desa.

Kewenangan dapat diartikan sebagai kekuasaan dan hak seseorang maupun lembaga dalam melakukan sesuatu, mengambil keputusan, atau mengorganisir masyarakat. Kewenangan sendiri berbeda dengan kekuasaan karena kewenangan lebih pada hak untuk melakukan sesuatu, sementara kekuasaan adalah kemampuan untuk melakukan sesuatu. Adapun kewenangan yang diberikan kepada desa berdasarkan peraturan perundangan pada dasarnya ada tiga kewenangan yaitu: ${ }^{20}$

1. Kewenangan berdasarkan hak asal usul

Kewenangan ini adalah hak yang merupakan warisan yang masih hidup dan prakarsa desa atau prakarsa masyarakat desa sesuai dengan perkembangan kehidupan masyarakat. Kewenangan berdasarkan hak asal usul meliputi: 21
a. penataan sistem organisasi dan kelembagaan masyarakat adat;
b. pranata hukum adat;
c. pemilikan hak tradisional;
d. pengelolaan tanah kas Desa adat;
e. pengelolaan tanah ulayat;
f. kesepakatan dalam kehidupan masyarakat Desa adat;
g. pengisian jabatan kepala Desa adat dan perangkat Desa adat; dan
h. masa jabatan kepala Desa adat.

2. Kewenangan lokal berskala desa

Kewenangan ini adalah kewenangan untuk mengatur dan mengurus kepentingan masyarakat desa yang telah dijalankan oleh desa atau mampu dan efektif dijalankan oleh desa atau yang muncul karena perkembangan desa dan prakasa masyarakat Desa. Kewenangan ini bentuknya adalah:

20 Sutoro Eko, Buku Pintar Kedudukan dan Kewenangan Desa, Forum Pengembangan Pembaharuan Desa (FPPD), Jakarta, 2014, hlm. 6

${ }_{21}$ Pasal 3 Permendesa Nomor 01 Tahun 2015 tentang Pedoman Kewenangan Berdasarkan Hak Asal Usul Dan Kewenangan Lokal Berskala Desa 
b. kewenangan yang mempunyai lingkup pengaturan dan kegiatan hanya di dalam wilayah dan masyarakat Desa yang mempunyai dampak internal Desa;

c. kewenangan yang berkaitan dengan kebutuhan dan kepentingan seharihari masyarakat Desa;

d. kegiatan yang telah dijalankan oleh Desa atas dasar prakarsa Desa;

e. program kegiatan pemerintah, pemerintah provinsi, dan pemerintah kabupaten/kota dan pihak ketiga yang telah diserahkan dan dikelola oleh Desa; dan

f. kewenangan lokal berskala Desa yang telah diatur dalam peraturan perundang-undangan tentang pembagian kewenangan pemerintah, pemerintah provinsi, dan pemerintah kabupaten/kota.

3. Kewenangan oleh Pemerintah

Kewenangan ini adalah kewenangan yang ditugaskan oleh Pemerintah, Pemerintah Daerah Provinsi, atau Pemerintah Daerah Kabupaten/Kota yang sesuai dengan ketentuan peraturan perundang-undangan.

Ketiga kewenangan tersebut wajib diketahui oleh Pemerintah Desa karena tanpa mengetahui kewenangan tersebut pemerintah desa akan mengalami kesulitan dalam membuat aturan di tingkat desa. Adapun kewenangan bidang kesehatan sebagai satu kewenangan lokal berskala Desa di bidang pelayanan dasar diatur dalam Pasal 9 huruf a antara lain meliputi:

a. pengembangan pos kesehatan Desa dan Polindes;

b. pengembangan tenaga kesehatan Desa;

c. pengelolaan dan pembinaan Posyandu melalui:

1. layanan gizi untuk balita;

2. pemeriksaan ibu hamil;

3. pemberian makanan tambahan;

4. penyuluhan kesehatan;

5. gerakan hidup bersih dan sehat;

6. penimbangan bayi; dan

7. gerakan sehat untuk lanjut usia.

d. pembinaan dan pengawasan upaya kesehatan tradisional;

e. pemantauan dan pencegahan penyalahgunaan narkotika dan zat adiktif di Desa.

Melihat uraian dalam peraturan Permendesa Nomor 01 Tahun 2015 tersebut dapat dilihat bahwa pemerintah desa memiliki kewenangan untuk mengatur dan mengurus urusan kesehatan di tingkat desa. Sebenarnya dengan adanya aturan tersebut menjadi satu kesempatan bagi desa untuk meningkatkan kesehatan bagi masyarakat. Hal ini sejalan dengan landasan filosofis dana desa yakni untuk 
meningkatkan kesejahteraan dan pemerataan bagi masyarakat. Terlebih jika melihat setiap tahunnya kementerian Desa mengeluarkan Peraturan Menteri mengenai prioritas Penggunaan dana desa dimana di dalamnya kesehatan selalu menjadi satu bidang yang prioritas. Penggunaan dana desa sesuai prioritas adalah satu prinsip penggunaan dana desa. ${ }^{22}$ Namun dalam laporan yang diterbitkan oleh Kementerian Keuangan Republik Indonesia menyatakan bahwa aloaksi dana desa tidak sesuai karena penggunaannya yang tidak sesuai dengan prioritas. ${ }^{23}$

Adapun prioritas dana desa 2019 diatur dalam Permen Desa PDTT 16 Tahun 2018 dimana urusan kesehatan di atur dalam Pasal 4 ayat (3) yang diwujudkan dalam upaya peningkatan gizi masyarakat serta pencegahan anak kerdil (stunting). Kegiatan pelayanan gizi dan pencegahan anak kerdil (stunting) sebagaimana dimaksud meliputi:

a. penyediaan air bersih dan sanitasi;

b. pemberian makanan tambahan dan bergizi untuk balita;

c. pelatihan pemantauan perkembangan kesehatan ibu hamil atau ibu menyusui;

d. bantuan posyandu untuk mendukung kegiatan pemeriksaan berkala kesehatan ibu hamil atau ibu menyusui;

e. pengembangan apotek hidup desa dan produk hotikultura untuk memenuhi kebutuhan gizi ibu hamil atau ibu menyusui;

f. pengembangan ketahanan pangan di Desa; dan

g. kegiatan penanganan kualitas hidup lainnya yang sesuai dengan kewenangan Desa dan diputuskan dalam musyawarah Desa.

Kewenangan Pemerintah desa untuk menggunakan dana desa juga diatur dalam Keputusan Menteri Kesehatan RI No: HK.02.02/Menkes/52/2015 tentang Rencana Strategis Kementerian Kesehatan 2015-2019, salah satu butirnya adalah mendorong desa untuk mengalokasi dan memanfaatkan dana desa minimal 10\% untuk UKBM.

22 Permendesa PDTT mulai 2015 hingga 2019 selalu memprioritaskan kesehatan berbasis pemberdayaan masyarakat sebagai prioritas.

${ }^{23}$ Kementerian Keuangan RI, Op. Cit., hlm. 12 
Peran Pemerintah Desa dalam Pemanfaatan Dana Desa untuk Kegiatan Bidang
Kesehatan di Kabupaten Banyumas

Pengalokasian dana desa minimal 10 \% untuk dana desa melalui UKBM sudah diatur jelas dalam peraturan perundang-undangan. Namun, di Kabupaten Banyumas berdasarkan data yang penulis temukan di lapangan yakni 50 desa di Kabupaten Banyumas pada 2019 ditemukan bahwa pengaloaksian dana desa untuk kesehatan masih di bawah 10\%. Padahal Banyumas memiliki indeks pembangunan manusia dengan nilai 71,3 . Sebagai contoh kasus stunting di Banyumas yang masih banyak yakni pada 2019 kasus stunting di wilayah Kecamatan Purwokerto Utara ada 261 kasus, Purwokerto Selatan ada 17 kasus, Purwokerto Timur ada 375 kasus, dan Purwokerto Barat ada 389 kasus jika ditotalkan mencapai 1.042 kasus stunting. Selain stunting angka Kematian Bayi di Kabupaten Banyumas sebesar 7,84 per 1.000 kelahiran hidup. Angka Kematian Balita adalah sebesar 8,94 per 1.000. Angka Kematian Ibu adalah sebesar 67,84 per 100.000 kelahiran hidup. Angka Notifikasi Kasus TB BTA+ adalah sebesar 214,57 per 100.000 penduduk. Jumlah kasus HIV adalah sebanyak 221 kasus, dan AIDS 136 kasus, dengan jumlah kematian akibat AIDS 25 kasus. Temuan kasus Kusta baru ada 1 kasus Kusta Kering dan 28 kasus Kusta Basah. ${ }^{24}$

Melihat profil kesehatan Banyumas yang masih ditemukan banyaknya kasus kesehatan di tengah aloaksi dana desa Kabupaten Banyumas sebesar lebih dari tiga milyar rupiah atau sebesar Rp. 360.743.521,00.25 Artinya masih banyak alokasi dana desa yang belum dialoaksikan untuk pembangunan kesehatan. Padahal pembangunan kesehatan memiliki arti penting yakni apabila pembangungan kesehatan masyarakat dibangkitkan disamping meningkatkan pembangunan infrastruktur di desa maka penduduk di desa dapat mencapai pada usia harapan hidup yang panjang dengan berbagai kegiatan yang bisa dicapai misalnya posyandu, posyandu lansia, program penekanan angka kematian ibu dan bayi baru lahir.

${ }^{24}$ BPS Kabupaten Banyumas, Profil Kesehatan Kabupaten Banyumas, Dinas Kesehatan Banyumas, Banyumas, 2019, hlm 4

25 Alokasi Dana Desa 2019, http://www.djpk.kemenkeu.go.id/wp-content/uploads/2018/10/DANADESA.pdf diakses pada 27 November 2020 
Data yang penulis temukan dari 50 desa di Kabupaten Banyumas dengan transfer dana desa yang besar, namun alokasi dana desa untuk kesehatan masih di bawah $10 \%$ di mana alokasi kegiatan untuk bidang kesehatan merupakan bagian dari kegiatan bidang Pembangunan. Berikut data yang penulis temukan:

Tabel 1

Tabel Penggunaan Dana Desa di Kabupaten Banyumas

\begin{tabular}{|c|c|c|c|c|}
\hline No & Nama Desa & $\begin{array}{l}\text { Pagu Dana } \\
\text { Desa }\end{array}$ & $\begin{array}{c}\text { Kegiatan } \\
\text { Pembangunan }\end{array}$ & $\begin{array}{c}\text { Kegiatan } \\
\text { Kesehatan }\end{array}$ \\
\hline 1 & Tumiyang & 939.762 .000 & 1.548 .897 .175 & 76.804 .900 \\
\hline 2 & Adisana & 1.335.017.000 & 1.723 .573 .000 & 78.103 .300 \\
\hline 3 & Bangsa & 1.240 .804 .000 & 2.009.221.500 & 196.854 .500 \\
\hline 4 & Karangsari & 1.291.279.000 & 1.718.627.810 & 24.050 .000 \\
\hline 5 & Sawangan & 986.927.000 & 1.007.875.700 & 109.848 .700 \\
\hline 6 & Kebasen & 1.222 .760 .000 & 1.634.497.400 & 86.619.000 \\
\hline 7 & Mandirancan & 997.734 .000 & 1.189 .464 .000 & 96.795 .500 \\
\hline 8 & Cindaga & 1.649.705.000 & 3.384.137.276 & 60.400 .500 \\
\hline 9 & Binangun & 1.239.101.000 & 911.674 .300 & - \\
\hline 10 & Pasinggangan & 1.767.398.000 & 1.728.344.000 & 69.110 .000 \\
\hline 11 & Kedunggede & 1.068.907.000 & 1.019.528.892 & 36.740 .000 \\
\hline 12 & Karangrau & 1.390.777.000 & 1.187.666.700 & 49.340 .900 \\
\hline 13 & Kejawer & 986.716 .000 & 739.890 .080 & 36.335 .000 \\
\hline 14 & Danaraja & 838.593 .000 & 813.942 .618 & 13.474 .200 \\
\hline 15 & Kedunguter & 880.163 .000 & 913.062 .060 & 261.392 .400 \\
\hline 16 & Sudagaran & 801.055 .000 & 614.772 .750 & 250.675 .750 \\
\hline 17 & Pakunden & 934.168 .000 & 863.431 .929 & 84.304 .500 \\
\hline 18 & Kalisube & 1.006 .408 .000 & 600.482 .500 & 36.800 .000 \\
\hline 19 & Dawuhan & 1.023.384.000 & 909.014 .500 & 26.627 .500 \\
\hline 20 & Papringan & 1.119 .586 .000 & 1.075.707.500 & 15.563 .000 \\
\hline 21 & Karangsari & 1.060.422.000 & 1.524 .519 .000 & 70.905 .000 \\
\hline 22 & Pliken & 1482.946 .000 & 1.835 .023 .600 & 61.125 .000 \\
\hline 23 & Purwadadi & 921.887 .000 & 774.786 .670 & 6.256 .000 \\
\hline 24 & Karang Tengah & 1.001.140.000 & 669.032 .788 & 24.275 .000 \\
\hline 25 & Kramat & 946.265 .000 & 1.250 .152 .000 & 105.420 .000 \\
\hline 26 & Karang Soka & 938.436 .000 & 1.039.132.100 & 27.600 .500 \\
\hline 27 & Tambaksari Kidul & 1.021 .758 .000 & 1.400.120.970 & 112.218 .500 \\
\hline 28 & Bantarwuni & 1.125 .016 .000 & 1.536 .813 .592 & 84.339 .000 \\
\hline 29 & Sambeng Kulon & 995.682 .000 & 959.537.804 & 71.002 .500 \\
\hline 30 & Purbadana & 1.050 .144 .000 & 1.344 .732 .450 & 15.602 .000 \\
\hline 31 & Bojongsari & 1.231 .925 .000 & 1.886 .633 .050 & 504.375 .800 \\
\hline 32 & Sialado & 970.660 .000 & 830.931.123 & 18.821 .000 \\
\hline 33 & Karangturi & 1.022 .091 .000 & 434.999 .500 & 68.400 .500 \\
\hline 34 & Karangcegak & 1.023 .697 .000 & 774.199 .700 & 146.873 .300 \\
\hline 35 & Sumbang & 1.431.291.000 & 666.839 .745 & 227.378 .470 \\
\hline
\end{tabular}




\begin{tabular}{llrrr}
\hline 36 & Tambaksogra & 1.241 .983 .000 & 794.224 .680 & 71.710 .000 \\
37 & Kebanggan & 1.161 .086 .000 & 971.015 .000 & 36.950 .000 \\
38 & Kawungcarang & 923.144 .000 & 552.747 .700 & 31.935 .700 \\
39 & Karanggintung & 1.170 .099 .000 & 1.053 .810 .125 & 43.490 .500 \\
40 & Datar & 1.083 .589 .000 & 831.196 .100 & 73.793 .700 \\
41 & Banjarsari Kulon & $1,208.601 .000$ & 662.160 .050 & 47.984 .250 \\
42 & Banjarsari Wetan & 1.104 .364 .000 & 913.818 .500 & 50.245 .500 \\
43 & Banteran & 1.541 .695 .000 & 969.027 .500 & 61.540 .000 \\
44 & Ciberem & 1.293 .990 .000 & 872.123 .740 & 36.170 .000 \\
45 & Susukan & 1.247 .514 .000 & 798.479 .650 & 38.551 .650 \\
46 & Siakapat & 1.377 .177 .000 & 1.053 .750 .700 & 6.294 .400 \\
47 & Gandatapa & 1.790 .355 .000 & 1.405 .611 .620 & 51.605 .800 \\
48 & Kotayasa & 2.002 .787 .000 & 1.641 .283 .575 & 42.970 .950 \\
49 & Limpakuwus & 1.723 .846 .000 & 1.251 .381 .250 & 25.000 .000 \\
50 & Kedungmalang & 938.222 .000 & 609.331 .150 & 30.112 .600 \\
\hline TOTAL & $\mathbf{5 8 . 7 5 2 . 0 5 6 . 0 0 0}$ & $\mathbf{5 6 . 9 0 1 . 2 2 7 . 1 2 2}$ & $\mathbf{3 . 8 0 2 . 7 8 7 . 2 7 0}$ \\
\hline
\end{tabular}

Sumber : Laporan Ralisasi Penggunaan Dana Desa Tahun 2019 di Kabupaten Banyumas 26

Jika diprosentasikan dana untuk pembangunan sebesar $97 \%$ dan dana untuk bidang kesehatan sebesar hanya 6\%. Perbandingan pengalokasian tersebut dikarenakan peran pemerintah desa yang masih belum semua mengetahui tentang pengalokasian dana desa untuk kesehatan dan masih berparadigma pengaloaksian dana desa untuk infrastruktur dengan pendekatan sesuai dengan Peraturan Menteri Dalam Negeri Nomor 113 Tahun 2014 tentang Pengelolaan Keuangan Desa yang mana pengaalokasiannya adalah $70 \%$ untuk fisik. Peran desicional yang masih rendah dari pemerintah desa diakibatkan belum adanya pemahaman yang merata bagi pemerintah desa terkait adanya prioritas penggunaan dana desa untuk kesehatan. Kesehatan adalah bentuk layanan sosial dasar bagi masyarakat sehingga menajdi sebuah ironi apabila terdapat dana desa yang besar namun masih terdapat kasus kesehatan yang menimpa warga.

Selain itu terdapat data tentang kegiatan yang sudah dilaksanakan untuk kegiatan bidang kesehatan menggunakan dana desa di 50 Desa di Kabupaten Banyumas, diantaranya adalah

1. fasilitas pelayanan kesehatan dan penanggulangan penyakit untuk masyarakat Banyumas.

${ }^{26}$ Data telah diolah oleh penulis merujuk dari Data Laporan Penggunaan Dana Desa 2019 di Kabupaten 
2. Pembangunan dan Pemeliharaan Sarana/Prasarana Kesehatan yang ada di Desa

3. Pembinaan dan Sosialisasi Kesehatan Kepada Masyarakat

4. Pemantauan dan pencegahan penyalahgunaan NAPZA di Desa

Berdasarkan data yang ditemukan oleh penulis, kiranya kegiatan yang dilakukan oleh Pemerintah Desa masih belum berorientasi pada kegiatan kesehatan dengan pemberdayaan masyarakat, hal ini dikarenakan kegiatan Kesehatan merupakan bagian dari Bidang Pembangunan bukan menjadi bagin dari Bidang Pemberdayaan Masyarakat.

\section{Model Pemanfaatan Dana Desa untuk Kegiatan Bidang Kesehatan Masyarakat di Masa yang Akan Datang}

Berangkat dari masih sedikitnya dana desa yang dialokasikan untuk bidang kesehatan yang merupakan pelayanan dasar bagi masyarakat padahal sudah terdapat regulasi yang mengaturnya. Menurut Utomo, penerapan otonomi daerah dan desa memerlukan dukungan serta pengembangan suatu sistem pengelolaan pembangunan yang lebih mendorong keterlibatan masyarakat secara lebih luas supaya dalam implementasinya otonomi desa tidak menyimpang dari kepentingan masyarakat. Hal ini juga untuk mewujudkan pemerintahan desa yang jujur, terbuka, bertanggung jawab, dan juga demokratis (good governance).27

Pengalokasian dana desa 10\% untuk kesehatan ke depannya harus dilakukan secara optimal karena sesuai dengan arah paradigma sistem pembangunan baru yang berorientasi pada pembangunan manusia bukan hanya pembangunan infrastruktur berbasis ekonomi. Untuk itu perlunya satu model yang tepat untuk pemanfaatan dana desa bagi kesehatan melalui sebuah sistem yakni, pertama, diterapkannya pola buttom up dalam perencanaan pembangunan desa yakni melalaui serap aspirasi dari masyarakat luas dengan pendataan sensus kesehatan rutin setiap tahun yang dilakukan oleh pemerintah desa. Hasil sensus kesehatan tersebut nantinya diamsukan dalam RKP Desa untuk pemanfaatan dana desa. Setelah sensus kesehatan dilakukan maka akan ditemukan problematika kesehatan dalam masyarakat sehingga dapat dirumuskan arah

\footnotetext{
27 Slamet Joko Utomo, "Implementasi Kebijakan Anggaran Pendapatan dan Belanja Desa (ABDesa) untuk Meningkatkan Pembangunan Desa” Media Trend, Vol. 10 No. 1 Maret 2015, hlm. 27-46.
} 
pembangunan kesehatan berorientasi pemberdayaan masyarakat. Kedua, pembentukan tim percepatan IPM di tingkat Kabupaten yang kemudian turun untuk memberikan edukasi kepada desa. Ketiga, pembentukan peer education kepada masyarakat oleh tim yang diketuai oleh tenaga medis yang dimiliki oleh masyarakat desa seperti bidan desa yang nantinya akan membentuk satu buah gugus tugas kesehatan desa seperti kader desa, pelayanan posyandu, dan pencegahan penyakit. Keempat, adanya sosialisasi dan monitoring berkala dari kementerian kesehatan, kementerian desa dan kementerian dalam negeri untuk menyadarkan peran pemerintah desa bahwa anggaran dana desa bukan hanya untuk kegiatan pembangunan infrastruktur namun untuk pemberdayaan masyarakat khususnya kesehatan terlebih telah adanya peraturan mengenai penetapan prioritas penggunaan dana desa setiap tahunnya.

\section{Penutup}

Berdasarkan hasil penelitian dan pembahasan, dalam penelitian ini menyimpulkan tiga hal. Pertama, kewenangan bidang kesehatan yang dimiliki oleh pemerintah desa sebagai satu kewenangan lokal berskala Desa di bidang pelayanan dasar diatur dalam Pasal 9 huruf a yakni Permendesa Nomor 01 Tahun 2015 tentang Prioritas Penggunaan Dana Desa dan ditegaskan dalam Keputusan Menteri Kesehatan RI No: HK.02.02/Menkes/52/2015 tentang Rencana Strategis Kementerian Kesehatan 2015-2019, di mana di dalamnya ditegaskan bahwa dana desa dapat dialokasikan untuk kesehatan sebesar 10\%. Untuk mewujudkan target alokasi tersebut pemerintah melalui lembaga/kementrian terkait perlu melakukan pembinaan dan sosialisasi yang cukup masif kepada pemerintah desa, agar dana desa dapat dimaksimalkan untuk peningkatan kesehatan masyarakar.

Kedua, di Kabupaten Banyumas pengaloaksian dana desa masih jauh dari angka 10\% untuk bidang kesehatan, di mana dari 50 desa di Banyumas pengaloaksian dana desa baru sebesar 6\% saja, hal ini dikarenakan peran pemerintah desa yang masih belum maksimal akibat ketidaktahuan dalam prioritas dana desa untuk kesehatan. Perlu adanya optimalisasi peran pendamping desa dalam melakukan pendampingan kepada pemerintah desa ketika menyusun anggaran desa khususnya dalam penggunaan dana desa untuk 
bidang kesehatan masyarakat. Ketiga, akibat dari permasalahan yang terjadi dibutuhkan model pemanfaatan dana desa di masa yang akan datang berupa penerapan sistem buttom up perencanaan pembangunan desa, sensus kesehatan desa setiap tahun, pembentukan peer education kesehatan di desa dan sosialisasi dan monitoring dari pemerintah untuk penggunaan dan pemanfaatan dana desa untuk kesehatan.

\section{Daftar Pustaka}

\section{Buku}

BPS Kabupaten Banyumas, Profil Kesehatan Kabupaten Banyumas, Dinas Kesehatan Banyumas, Banyumas, 2019.

Kementerian Keuangan RI, Buku Saku Dana Desa, Kemenkeu, Jakarta, 2018.

M. Salahudin, Buku 1 Kewenangan Desa dan Regulasi Desa, Cetakan Pertama, Kementrian Desa PDTT RI, Jakarta, 2015.

Sutoro Eko, Buku Pintar Kedudukan dan Kewenangan Desa, Forum Pengembangan Pembaharuan Desa (FPPD), Jakarta, 2014.

Zudan Arif Fakrulloh, Hukum Indonesia dalam Berbagai Prespektif, cetakan pertama, RajaGrafindo Persada, Jakarata, 2014.

\section{Jurnal}

Adelfina dan Jember, I Made, "Pengaruh Pertumbuhan Ekonomi, Kemiskinan, dan Belanja Daerah Terhadap Indeks Pembangunan Manusia Di Kabupaten Kota Provinsi Bali Periode 2005-2013." E-Jurnal Ekonomi Pembangunan Universitas Udayana. Vol. 5. No. 10 Oktober 2016.

Kushandajani, "Konstruksi Hukum Pemerintahan Desa: Pemikiran Perubahan Kebijakan bagi Desa". POLITIKA, Jurnal Magister Ilmu Politik UNDIP, Vol. 2 No. 1, April 2011.

Maman Saputra, "Program Jaminan Kesehatan Nasional Dari Aspek Sumber Daya Manusia Pelaksana Pelayanan Kesehatan", KEMAS Jurnal Kesehatan Masyarakat, Vol. 11 No. 1, 2015.

Rif'atul Hidayat, "Hak Atas Derajat Pelayanan Kesehatan Yang Optimal", SYARIAH Jurnal Hukum dan Pemikiran, Vol. 16, No. 2, Desember 2016.

Slamet Joko Utomo, "Implementasi Kebijakan Anggaran Pendapatan dan Belanja Desa (ABDesa) untuk Meningkatkan Pembangunan Desa" Media Trend, Vol. 10 No. 1 Maret 2015.

Soekidjo, "Kesehatan dan Pembangunan Sumber Daya Manusia", Jurnal Kesehatan Masyarakat Nasional, Vol. 2, No. 5, April 2010. 


\section{Internet}

"Program Indonesia Sehat dengan Pendekatan Keluarga",

https:/ / www.kemkes.go.id/article/view/17070700004/program-indonesiasehat-dengan-pendekatan-keluarga.html, diakses pada 25 November 2020

"Indeks Pembangunan Manusia Kabupaten Banyumas Tahun 2014-2018" https:/ / banyumaskab.bps.go.id/statictable/2019/08/22/181/indekspembangunan-manusia-kabupaten-banyumas-tahun-2014-2018.html diakses 25 November 2020

"Pemdes Banyumas manfaatkan Dana Desa kembangkan pariwisaata", https://jateng.antaranews.com/berita/208476/pemdes-banyumasmanfaatkan-dana-desa-kembangkan-pariwisaata diakses pada 24 November 2020

"Jumlah Desa di Indonesia 2018", https://databoks.katadata.co.id/ datapublish/2019/06/13/berapa-jumlah-desa-di-indonesia, diakses pada 26 November 2020

Alokasi Dana Desa 2019, http://www.djpk.kemenkeu.go.id/wp-content/ uploads/2018/10/DANA-DESA.pdf diakses pada 27 November 2020 